\title{
Nucleic Acid
}

National Human Genome Research Institute (NHGRI)

\section{Source}

National Human Genome Research Institute (NHGRI). Nucleic Acid.

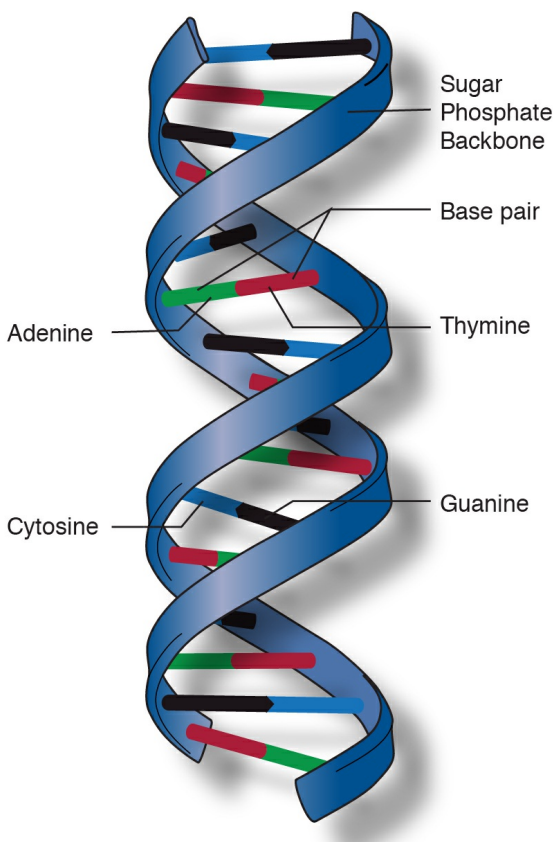

Deoxyribonucleic acid (DNA)

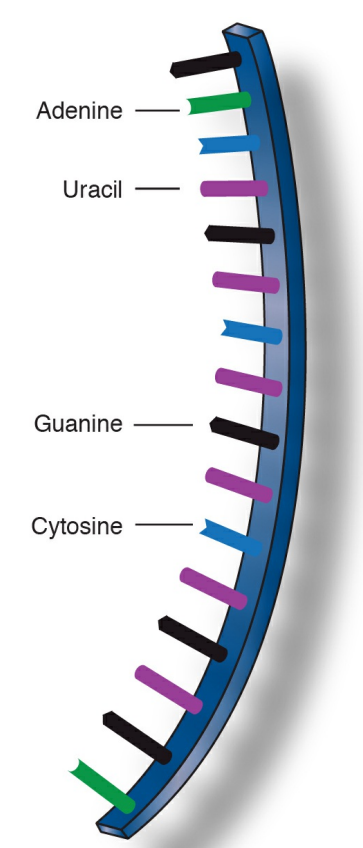

Ribonucleic acid (RNA)

Nucleic acid is an important class of macromolecules found in all cells and viruses. The functions of nucleic acids have to do with the storage and expression of genetic information. Deoxyribonucleic acid (DNA) encodes the information the cell needs to make proteins. A related type of nucleic acid, called ribonucleic acid (RNA), comes in different molecular forms that participate in protein synthesis. 